\title{
Oestrogen receptor status, treatment and breast cancer prognosis in Icelandic BRCA2 mutation carriers
}

Jon G Jonasson 1,2,3, Olafur A Stefansson ${ }^{4}$, Oskar T Johannsson 2,5,6, Helgi Sigurdsson 2,5 , Bjarni A Agnarsson ${ }^{2,3}$, Gudridur H Olafsdottir ${ }^{1}$, Kristin K Alexiusdottir ${ }^{1,5}$, Hrefna Stefansdottir ${ }^{1}$, Rodrigo Munoz Mitev ${ }^{3}$, Katrin Olafsdottir ${ }^{3}$, Kristrun Olafsdottir ${ }^{3}$, Adalgeir Arason ${ }^{7}$, Vigdis Stefansdottir ${ }^{6}$, Elinborg J Olafsdottir ${ }^{1}$, Rosa B Barkardottir ${ }^{2,7,8}$, Jorunn E Eyfjord ${ }^{2,4}$, Steven A Narod ${ }^{9}$ and Laufey Tryggvadóttir ${ }^{\star, 1,2}$

${ }^{1}$ Icelandic Cancer Registry, Icelandic Cancer Society, Reykjavik, Iceland; ${ }^{2}$ Faculty of Medicine, Laeknagardur, University of Iceland, Reykjavik, Iceland; ${ }^{3}$ Department of Pathology, Landspitali University Hospital, Reykjavik, Iceland; ${ }^{4}$ Cancer Research Laboratory, Biomedical Centre, School of Health Sciences, University of Iceland, Reykjavik, Iceland; ${ }^{5}$ Department of Oncology, Landspitali University Hospital, Reykjavik, Iceland; ' ${ }^{6}$ epartment of Genetics and Molecular Medicine, University Hospital, Reykjavik, Iceland; ${ }^{7}$ Laboratory of Cell Biology, Department of Pathology, University Hospital, Reykjavik, Iceland; ${ }^{8}$ Biomedical Centre, School of Health Sciences, University of Iceland, Reykjavik, Iceland and 'Womens' College Research Institute, University of Toronto, Toronto, ON, Canada

Background: The impact of an inherited BRCA2 mutation on the prognosis of women with breast cancer has not been well documented. We studied the effects of oestrogen receptor (ER) status, other prognostic factors and treatments on survival in a large cohort of BRCA2 mutation carriers.

Methods: We identified 285 breast cancer patients with a 999del5 BRCA2 mutation and matched them with 570 non-carrier patients. Clinical information was abstracted from patient charts and pathology records and supplemented by evaluation of tumour grade and ER status using archived tissue specimens. Univariate and multivariate hazard ratios (HR) were estimated for breast cancer-specific survival using Cox regression. The effects of various therapies were studied in patients treated from 1980 to 2012.

Results: Among mutation carriers, positive ER status was associated with higher risk of death than negative ER status $(\mathrm{HR}=1.94 ; 95 \% \mathrm{Cl}=1.22-3.07, P=0.005)$. The reverse association was seen for non-carriers ( $\mathrm{HR}=0.71 ; 95 \% \mathrm{Cl}: 0.51-0.97 ; P=0.03)$.

Conclusions: Among BRCA2 carriers, ER-positive status is an adverse prognostic factor. BRCA2 carrier status should be known at the time when treatment decisions are made.

Under the precision medicine initiative, women with breast cancer stand to benefit from treatments that are tailored specifically to their tumour type and to individual host factors (Collins and Varmus, 2015). There is increasing evidence that specific variants in a patient's genotype may be independent predictors of breast cancer survival or response to treatment. For example, women with breast cancer and a BRCA1 mutation benefit from oophorectomy,
(Huzarski et al, 2013; Metcalfe et al, 2015) and respond to cisplatinum (Byrski et al, 2010) and to olaparib (Lee, et al, 2014) more than do patients without a BRCA1 mutation. Much of the information we have gathered to date about prognosis and response to therapy for $B R C A 1$ carriers comes from cohort studies of founder populations, in particular, studies of Jewish (Robson et al, 2004; Rennert et al, 2007) and Polish (Huzarski et al, 2013)

*Correspondence: Professor L Tryggvadóttir; E-mail: laufeyt@krabb.is

Received 19 February 2016; revised 12 July 2016; accepted 20 July 2016; published online 18 August 2016

(c) 2016 Cancer Research UK. All rights reserved 0007 - 0920/16 
women. Little is known about the clinical history of breast cancer in $B R C A 2$ carriers. In most countries, $B R C A 2$ mutations are rare and genetically diverse, making large-scale observational studies difficult. However, in countries where founder mutations are common, it is possible to conduct historical cohort studies whereby the genetic status of a patient diagnosed in the past is ascertained using stored tissue blocks (Rennert et al, 2007). The patient is then followed from diagnosis until the present.

In Iceland, the BRCA2 mutation 999del5 (also written c.771_775del5) is a common founder mutation. (Johannesdottir et al, 1996; Thorlacius et al, 1996) This five base-pair deletion is present in $0.8 \%$ of women in the general population (Thorlacius et al, 1997; Gudbjartsson et al, 2015) and in 7-8\% of breast cancer patients (Johannesdottir et al, 1996; Thorlacius et al, 1997). Other mutations in BRCA2 and BRCA1 are rare. Iceland is a small country that is noteworthy for keeping comprehensive national health records, which can be linked using a personal identification number.

We recently published preliminary results that, in breast cancer patients carrying the Icelandic founder mutation 999del5, a positive oestrogen receptor (ER) status predicts an adverse outcome (Tryggvadottir et al, 2013). It is important to verify those results in a larger study, and to find out whether the association between survival and ER status in this genetic subgroup might vary by treatment given. By combining genetic data from three sources we established a cohort of 285 women with breast cancer and the BRCA2 mutation 999del5, thus extending by 153 carriers our previous study of 109 cases (Tryggvadottir et al, 2013). The period of case ascertainment included patients treated before and after the introduction of chemotherapy and of hormonal treatments. We report here the effects of ER status, of other prognostic factors and of different treatments on the survival of BRCA2 mutation carriers and non-carriers over an 80-year period.

\section{MATERIALS AND METHODS}

Study population. Mutation-positive breast cancer cases and mutation-negative controls were identified from among 3577 women in Iceland with breast cancer who had been tested for the BRCA2 999del5 mutation in the period 1995-2012. These 3577 tested cases represent $58 \%$ of all 6160 incident cases of invasive breast cancer diagnosed from 1935 through 2012. The majority of the tested cases (2954 women) were diagnosed in 1980-2004, constituting $85 \%$ of all cases diagnosed in Iceland that period.

Mutation-positive cases. Testing took place in two genetics laboratories in Reykjavik, Iceland, in the context of several previous research projects that are described elsewhere, (Tulinius et al, 2002; Arason et al, 2010; Tryggvadottir et al, 2013) and the results have been combined to generate a cohort of mutation-positive breast cancer patients. The research projects were originally based on the Family Collection of the Icelandic Cancer Society that was founded in 1972 and consists of 995 breast cancer probands who were selected for genealogical tracing by defined periods of diagnosis and year of birth and thus unselected with respect to family history (Tulinius et al, 2002). They have been tested for the BRCA2 mutation 999del5, and so have their 374 relatives with breast cancer. In addition, testing was done on 723 cases diagnosed in 1979-1995 who participated in the nation-wide cohort study of the Icelandic Cancer Detection Clinic (Tryggvadottir et al, 2003) and on 1473 cases diagnosed in defined time intervals during the period 1986-2012, and finally on 12 cases with family history of breast cancer who participated in family studies of the Icelandic Cancer Society in 1988-2004 (Thorlacius et al, 1996). Thus, only $0.3 \%$ of the tested cases were selected on the basis of family history.
Of the 3577 women who underwent testing, 271 (7.6\%) were positive for the 999del5 mutation. We identified 14 additional mutation carriers with breast cancer through the Genetic Counseling Unit in Reykjavik (Stefansdottir et al, 2013) bringing the total to 285 cases.

Mutation-negative control patients. From among the 3306 mutation-negative cases, we identified two mutation-negative control patients for each of the 285 mutation carriers. The 570 non-carriers were matched at random to carriers on year of birth and year of diagnosis.

Prognostic factors and treatment. For each of the 855 patients we sought clinical and pathology information from several sources by record linkage. The population-based Icelandic Cancer Registry contains information on all incident breast cancer patients in the country since 1955 (Sigurdardottir et al, 2012). In addition, the Registry keeps a complete list of all breast cancer cases diagnosed from 1911 to 1954 (Snaedal, 1965). Pathological samples were obtained from the Department of Pathology, National University Hospital, where samples are available from 1935 onwards. Data on tumour size, nodal status, distant metastasis, tumour grade and ER status were extracted from pathology records when available. Electronic information on oophorectomies could only be retrieved for women who were alive on 1 January 1989 and onwards. Routine assessment of ER status was initiated in 1981 in Iceland. Dextran-coated charcoal assay was applied in the period 1981 to 1995, succeeded by immunohistochemical (IHC) staining. For cancers in this study diagnosed before 1981 IHC was used (see below). Routine assessment of tumour grade began in 1991. In the event that tumour grade was missing (139 mutation carriers and 282 non-carriers), original slides were reviewed (where available) or new slides prepared from archival tumour tissue and assessed for tumour grade. Similarly, information on ER status was not available for 382 cases; slides were obtained from archived tumour material for 339 of these and 323 slides were successfully stained and scored (leaving 59 women without information on ER status). ER expression was scored as positive when $>1 \%$ of tumour cell nuclei stained positive for ERs with immunohistochemistry. Information on treatment was abstracted from patient charts, date of death was ascertained by record linkage with Statistics Iceland and cause of death by record linkage with Statistics Iceland and the Directorate of Health. Data were obtained blinded with respect to mutation status.

The study was approved by the Icelandic Data Protection Authority (2006050307) and the National Bioethics Committee of Iceland (VSNb2006050001/03-16).

Statistical analysis. Mean values for continuous variables were compared for mutation carriers and non-carriers using the $t$-test statistic. The $\chi^{2}$-test was used for comparing proportions. All statistical tests were two-sided and $P$-values $<0.05$ were considered to be statistically significant.

Patients were followed from the date of diagnosis of first invasive breast cancer until death or last date of follow-up (31 December 2014). Of the 855 patients in the study, 584 had been tested for the mutation using a paraffin-embedded tumour specimen and 271 using a fresh blood specimen. Fixty-six cases had their blood sample taken $>2$ years after diagnosis. To avoid survivorship bias (Tilanus-Linthorst et al, 2006) we used left-truncated survival analysis, that is, the follow-up time began at the date of sampling for all women who were genetically tested using blood samples taken after diagnosis. Patients who died of causes other than breast cancer were censored at the date of death. The Kaplan-Meier method was used for generating univariable survival curves and the log-rank test was used for estimating $P$-values. Adjusted hazard ratios (HRs) were estimated using the Cox proportional hazards model. In the multivariable analysis, the HR was adjusted for year of birth and year of diagnosis 
(continuous variables), tumour size, ( $<20 \mathrm{~mm} ; 20-50 \mathrm{~mm}$; $51+$ $\mathrm{mm}$ ), lymph node status (positive/negative), grade (I, II, III) and ER status (negative/positive). Oophorectomies were not included because data were only available for women who were alive from 1989 onwards.

We first evaluated prognostic factors for subgroups of patients defined by mutation status, including an interaction term for $B R C A 2$ mutation status and prognostic factors. Additional adjusted and stratified analyses were conducted to evaluate the effects of various treatments on the survival difference between mutation carriers and non-carriers, restricting the study group to patients treated from 1980 to 2012, that is, the era after the introduction of modern therapies. In this cohort study the matching variables (year of birth and year of diagnosis) were included in all Cox models according to Sjölander (Sjölander and Greenland, 2013). Hormonal treatment was restricted to tamoxifen before year 2000, but included aromatase inhibitors thereafter. Chemotherapy regimens were divided into those containing an anthracycline and those that did not contain an anthracycline. Patients with missing values were excluded from the Cox models. All analyses were performed using STATA Statistical Software Stata/IC 10.0 for Windows.

\section{RESULTS}

Tumour characteristics in carriers and non-carriers. Of the 855 patients, 21 patients who had metastatic disease at diagnosis were excluded, leaving 279 mutation-positive cases and 555 mutation-negative cases for analyses. The BRCA2 carriers had, on average, larger cancers than non-carriers $(2.7 \mathrm{~cm}$ vs $2.4 \mathrm{~cm}$; $P<0.001)$ and mutation carriers were more likely to present with positive lymph nodes (55\% vs 43\%; $P=0.001$ ) (Table 1). In BRCA2 carriers, $76 \%$ of the cancers were ER-positive, compared with $70 \%$ of the cancers in non-carriers $(P=0.11)$ and in $B R C A 2$ carriers, $12 \%$ were low grade, compared with $26 \%$ in non-carriers $(P<0.01)$.

In BRCA2 mutation carriers, women with ER-positive breast cancer were more likely to be node-positive than were women with ER-negative cancers $(63 \%$ vs $32 \% ; P<0.01)$ (Table 2). In mutation carriers, positive ER status was also positively associated with tumour size. In non-carriers, the opposite was true; positive ER status was associated with smaller cancers and with node-negative cancers (Table 2).

Tumour characteristics and survival. Increasing tumour size and positive lymph node status were associated with inferior breast cancer-specific survival, both among mutation carriers and noncarriers (Table 3). Tumour grade had significant prognostic value among non-carriers, but not among carriers although the test for interaction was not significant $(P=0.11)$. Over an 80 -year study period the proportion of cases with ER-positive tumours remained stable (Supplementary Figure 1). Among non-carriers, positive ER status was a favourable prognostic factor (HR adjusted for year of birth and year of diagnosis $0.71 ; 95 \% \mathrm{CI}=0.51-0.97 ; P=0.03$ ). Among carriers, women with ER-positive cancers did worse than women with ER-negative cancers $(\mathrm{HR}=1.94 ; 95 \% \mathrm{CI}=1.22-3.07$; $P=0.005 ; P$-value for interaction between carrier status and ER status; $P<0.001)$. When also adjusting for tumour size and lymph node status the HR comparing ER + tumours with ER - tumours changed from 0.71 to $0.72(0.49-1.05, P=0.09)$ for non-carriers and from 1.94 to $1.43(0.85-2.42, P=0.18)$ for mutation carriers. The association between positive ER status and poor survival among BRCA2 carriers was present in the period 1935-1979 $(\mathrm{HR}=1.97 ; 95 \% \mathrm{CI}=0.98-3.94, P=0.06)$ and in the period 1980 to $2012(\mathrm{HR}=1.75 ; 95 \% \mathrm{CI}=0.94-3.27, P=0.08)$ (Figure 1$)$.

Treatment and survival. The standard treatments were introduced into Iceland in the 1980s (Supplementary Figure 2) and therefore, in
Table 1. Clinical characteristics of breast cancer patients according to BRCA2 mutation status (period of diagnosis 1935-2012)

\begin{tabular}{|c|c|c|c|}
\hline Characteristic & Non-carriers & $\begin{array}{l}\text { BRCA2 } \\
\text { mutation }\end{array}$ & $P$-value \\
\hline Mutation status analysed (n) & $555^{\mathrm{a}}$ & $279^{a}$ & \\
\hline Year of birth, mean (range) & $\begin{array}{c}1935 \\
(1873-1980)\end{array}$ & $\begin{array}{c}1935 \\
(1874-1977)\end{array}$ & 0.93 \\
\hline $\begin{array}{l}\text { Year of diagnosis, mean } \\
\text { (range) }\end{array}$ & $\begin{array}{c}1985 \\
(1935-2012)\end{array}$ & $\begin{array}{c}1985 \\
(1935-2012)\end{array}$ & 0.86 \\
\hline $\begin{array}{l}\text { Age at diagnosis, mean } \\
\text { (range) }\end{array}$ & $49.4(26-82)$ & $49.5(21-82)$ & 0.93 \\
\hline $\begin{array}{l}\text { Second inv. contralat. breast } \\
\text { cancer }\end{array}$ & $6.7 \%$ & $18.6 \%$ & $<0.001$ \\
\hline $\begin{array}{l}\text { Morphology (n) } \\
\text { Ductal } \\
\text { Lobular } \\
\text { Other and unknown (n) }\end{array}$ & $\begin{array}{c}90.7 \% \\
9.3 \% \\
72\end{array}$ & $\begin{array}{c}87.8 \% \\
12.2 \% \\
26\end{array}$ & 0.21 \\
\hline $\begin{array}{l}\text { Size } \\
\text { Mean (mm) } \\
T 1 \leqslant 20 \mathrm{~mm} \\
T 2>20 \mathrm{~mm} \text { and } \leqslant 50 \mathrm{~mm} \\
T 3>50 \mathrm{~mm} \\
\text { Unknown }(\mathrm{n})\end{array}$ & $\begin{array}{c}23.9(1-110) \\
55.4 \% \\
38.8 \% \\
5.8 \% \\
89\end{array}$ & $\begin{array}{c}27.3(1-110) \\
47.1 \% \\
44.2 \% \\
8.7 \% \\
48\end{array}$ & $\begin{array}{l}0.01 \\
0.09\end{array}$ \\
\hline $\begin{array}{l}\text { Nodal involvement } \\
\text { No } \\
\text { Yes } \\
\text { Unknown ( } n) \\
\text { Detailed information }(n) \\
0 \text { positive nodes } \\
1-3 \text { positive nodes } \\
4-9 \text { positive nodes } \\
\geqslant 10 \text { positive nodes }\end{array}$ & $\begin{array}{c}57.0 \% \\
43.0 \% \\
55 \\
425 \\
66.8 \% \\
23.1 \% \\
6.6 \% \\
3.5 \%\end{array}$ & $\begin{array}{c}44.5 \% \\
55.5 \% \\
16 \\
220 \\
53.2 \% \\
24.1 \% \\
12.7 \% \\
10.0 \%\end{array}$ & $<0.001$ \\
\hline $\begin{array}{l}\text { Grade } \\
\text { 1-well differentiated } \\
\text { 2-moderately differentiated } \\
\text { 3-poorly differentiated } \\
\text { Unknown (n) }\end{array}$ & $\begin{array}{c}26.2 \% \\
46.8 \% \\
26.9 \% \\
42\end{array}$ & $\begin{array}{c}12.0 \% \\
52.1 \% \\
36.0 \% \\
12\end{array}$ & $<0.001$ \\
\hline $\begin{array}{l}\text { ER status } \\
\text { Negative } \\
\text { Positive } \\
\text { Unknown (n) } \\
\end{array}$ & $\begin{array}{c}29.8 \% \\
70.2 \% \\
52 \\
\end{array}$ & $\begin{array}{c}24.4 \% \\
75.6 \% \\
17 \\
\end{array}$ & 0.11 \\
\hline
\end{tabular}

order to evaluate the effects of the various treatments on survival in $B R C A 2$ carriers (and non-carriers) we restricted the following analyses to patients treated from 1980 onwards. In this period, the 15 -year actuarial breast cancer-specific survival for BRCA2 carriers was $55 \%(95 \% \mathrm{CI}=0.4-0.63 \%)$ and for non-carriers was $75 \%$ (95\% CI $=0.70-0.80 \%)$. Among BRCA2 carriers, the adjusted HR associated with mastectomy vs lumpectomy was 0.49 (95\% CI: $0.21-1.11 ; P=0.09)(\mathrm{p}$ for interaction $=0.007)($ Table 4$)$. Among carriers, the HR for chemotherapy (any) vs no chemotherapy was 0.35 (95\% CI, $0.16-0.80 ; P=0.01)$ ( $\mathrm{p}$ for interaction $=0.06$ ). Anthracyclines were the main type of chemotherapy in use after year 2000 (Supplementary Figure 2) and in 35\% of recipients they were accompanied by a taxane. Non-anthracycline regimens included CMF (58\%), CMF plus vincristine (37\%) and other regimens (only or with taxanes) (5\%). The beneficial effects of anthracyclines and of other chemotherapy regimens on survival in mutation carriers were similar (Table 4).

After adjustment for other prognostic factors and treatment, a positive BRCA2 status was associated with a significantly worse prognosis than a negative status $(\mathrm{HR}=1.61 ; 95 \% \mathrm{CI}=1.11-2.35$, $P=0.01$ ) (Table 5). This survival difference between the two subgroups was statistically significant among patients with ER-positive 
Table 2. Tumour characteristics according to BRCA2 status and ER status (period of diagnosis 1935-2012)

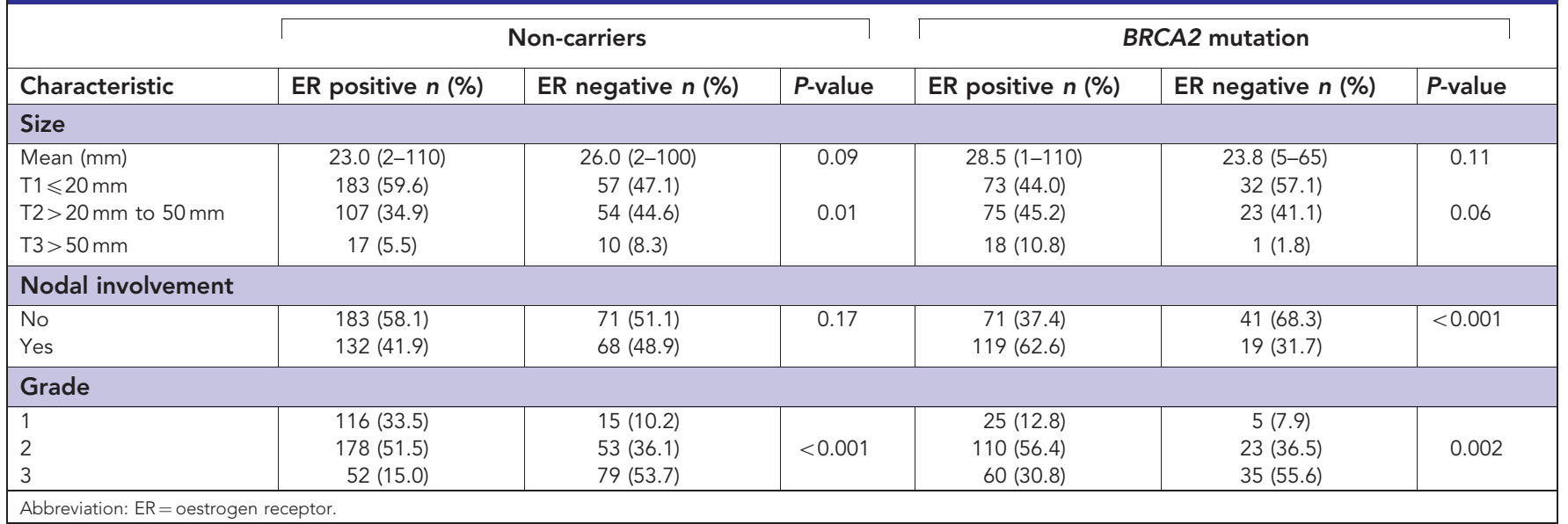

Table 3. Risk of breast cancer-specific death according to key tumour characteristics and BRCA2 mutation status (period of diagnosis 1935-2012), adjusted ${ }^{a}$

\begin{tabular}{|c|c|c|c|c|c|c|c|c|c|c|c|}
\hline \multirow[b]{2}{*}{ Characteristic } & \multicolumn{5}{|c|}{ Non-carriers } & \multicolumn{5}{|c|}{ BRCA2 mutation } & \multirow[b]{2}{*}{$\begin{array}{c}P \text {-value } \\
\text { interaction }\end{array}$} \\
\hline & Patients (n) & Deaths (n) & HR & $95 \% \mathrm{Cl}$ & $P$-value & Patients (n) & Deaths $(n)$ & HR & $95 \% \mathrm{Cl}$ & $P$-value & \\
\hline \multicolumn{11}{|l|}{ Size } & 0.14 \\
\hline $\begin{array}{l}\mathrm{T} 1 \leqslant 20 \mathrm{~mm} \\
\mathrm{~T} 2>20 \mathrm{~mm} \text { to } 50 \mathrm{~mm} \\
\mathrm{~T} 3>50 \mathrm{~mm}\end{array}$ & $\begin{array}{l}256 \\
179 \\
27\end{array}$ & $\begin{array}{l}51 \\
70 \\
17\end{array}$ & \begin{tabular}{|c|}
1 \\
1.95 \\
5.97
\end{tabular} & $\begin{array}{c}1.34-2.85 \\
3.41-10.45\end{array}$ & $\begin{array}{c}0.001 \\
<0.001\end{array}$ & $\begin{array}{c}109 \\
102 \\
20\end{array}$ & $\begin{array}{l}39 \\
53 \\
16\end{array}$ & $\begin{array}{c}1 \\
1.52 \\
3.48\end{array}$ & \begin{tabular}{|l|}
$0.99-2.33$ \\
$1.92-6.32$
\end{tabular} & $\begin{array}{c}0.06 \\
<0.001\end{array}$ & \\
\hline \multicolumn{11}{|l|}{ ER status } & $<0.001$ \\
\hline $\begin{array}{l}\text { Negative } \\
\text { Positive }\end{array}$ & $\begin{array}{l}150 \\
353\end{array}$ & $\begin{array}{c}58 \\
112\end{array}$ & \begin{tabular}{|c|}
1 \\
0.71 \\
\end{tabular} & $0.51-0.97$ & 0.03 & $\begin{array}{c}64 \\
198 \\
\end{array}$ & $\begin{array}{c}24 \\
107\end{array}$ & $\begin{array}{c}1 \\
1.94 \\
\end{array}$ & $1.22-3.07$ & 0.005 & \\
\hline \multicolumn{12}{|c|}{$\begin{array}{l}\text { Abbreviations: } \mathrm{Cl}=\text { confidence interval; } \mathrm{ER}=\text { oestrogen receptor; } \mathrm{HR}=\text { hazard ratio. } \\
\mathrm{a}_{\text {Model including year of birth and year of diagnosis. }} \\
\mathrm{b}_{\text {Interaction between } B R C A 2 \text { mutation status and the relevant variable. }}\end{array}$} \\
\hline
\end{tabular}

tumours $(\mathrm{HR}=1.92,95 \% \mathrm{CI}=1.20-3.05, P=0.006)$, but not among patients with ER-negative tumours $(\mathrm{HR}=1.12,95 \% \mathrm{CI}=0.54-2.31$, $P=0.77)$. In the subgroup of patients treated with lumpectomy, $B R C A 2$ carriers had a greater risk of death than non-carriers $(\mathrm{HR}=4.16 ; 95 \% \mathrm{CI}=1.88-9.17, P<0.001)$. In the subgroup of patients treated with mastectomy, the risk of death was similar in the two groups $(\mathrm{HR}=1.25 ; 95 \% \mathrm{CI}=0.82-1.93, P=0.30)$. Among women who did not receive adjuvant chemotherapy BRCA2 carriers had a worse prognosis than non-carriers $(\mathrm{HR}=2.38$; $95 \% \mathrm{CI}=1.31$ 4.34; $P=0.005$ ), whereas among patients treated with chemotherapy, the prognosis was similar for mutation carriers and non-carriers $(\mathrm{HR}=1.21 ; 95 \% \mathrm{CI}=0.74-2.00, P=0.5)$.

In Supplementary Figure 3 we present breast cancer-specific survival curves according to the use of chemotherapy among patients with ER-positive tumours. In general, women treated with chemotherapy have more aggressive disease than women who do not receive chemotherapy. Despite this, among women with a BRCA2 mutation, those treated with chemotherapy did better than women not treated with chemotherapy (this was not seen among non-carriers).

Contralateral breast cancer. Overall, $18.6 \%$ of the mutation carriers had a contralateral breast cancer, compared with $6.7 \%$ of non-carriers $(P<0.001)$ (Table 1$)$. The cumulative incidence of contralateral breast cancer at 20 years among mutation carriers was $35.3 \%$ (95\% CI $=26.2-46.4 \%)$.

\section{DISCUSSION}

In this population-based cohort study of breast cancer patients, positive ER status was associated with a poor prognosis in women with a $B R C A 2$ mutation. The mutation carriers had inferior long- 
A

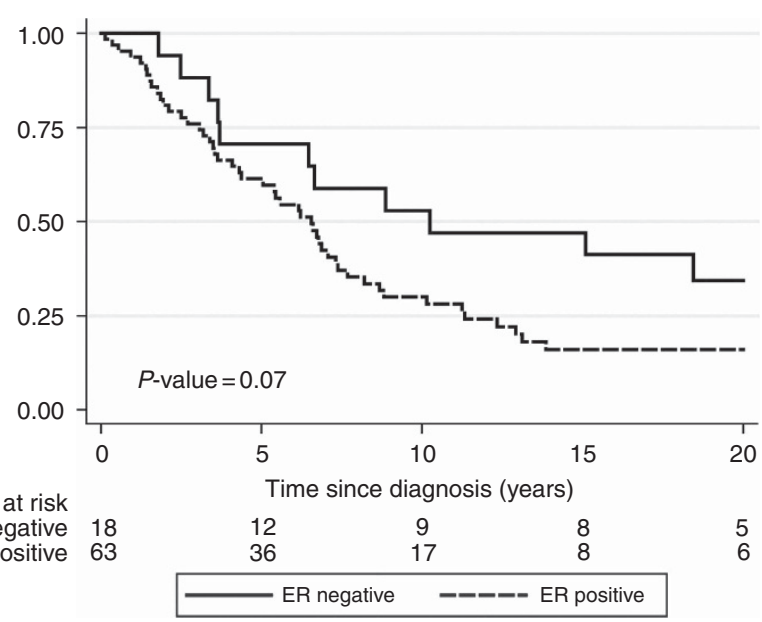

C

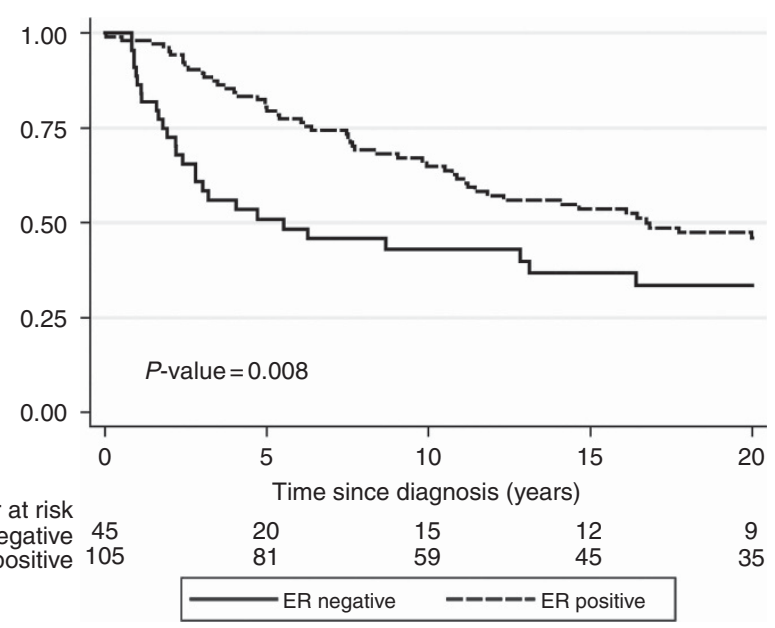

B

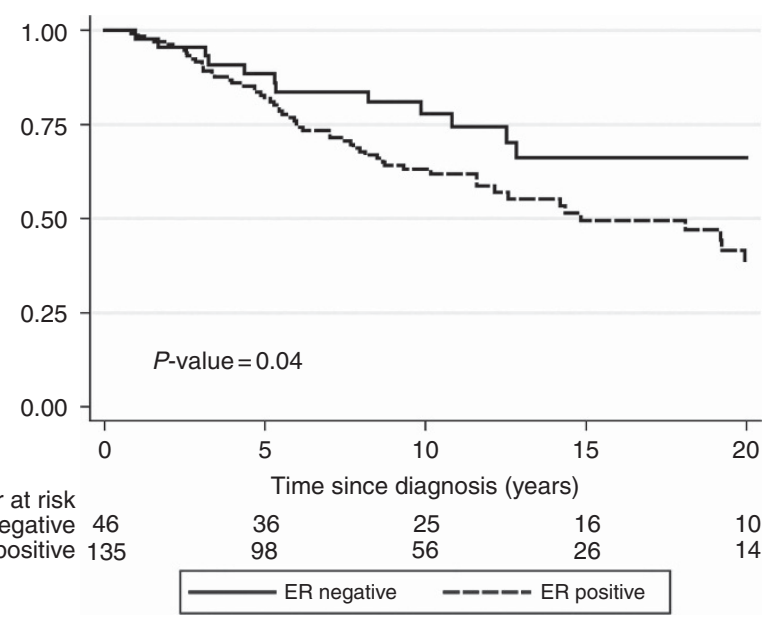

D

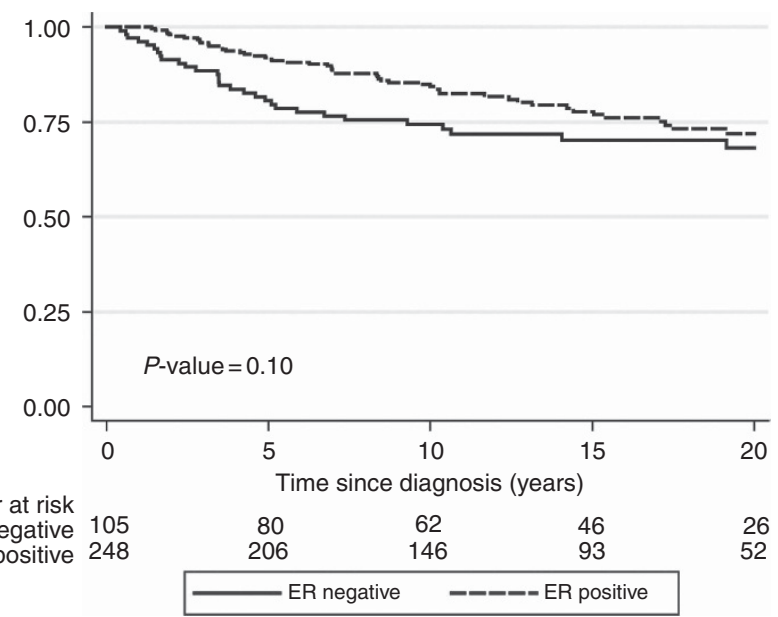

Figure 1. Breast cancer-specific survival probability according to ER status and the presence of a BRCA2 mutation in two time periods. (A) BRCA2 carriers diagnosed in 1935 through 1979. (B) BRCA2 carriers diagnosed in 1980 through 2012. (C) Non-carriers diagnosed in 1935 to 1979. (D) Non-carriers diagnosed in 1980 to 2012.

term survival than patients without a BRCA2 mutation, but this difference was mainly seen for women with ER-positive breast cancer. Presence of the BRCA2 mutation modified the association between ER status and survival, and in a subgroup analysis an adverse effect of having the BRCA2 mutation on prognosis was seen in women with ER-positive breast cancer ( $\mathrm{HR}=1.92 ; 95 \%$ $\mathrm{CI}=11.20-2.35 ; P=0.006)$ but not in women with ER-negative cancer $(\mathrm{HR}=1.12 ; 95 \% \mathrm{CI}=0.54-2.31 ; P=0.077)$.

The (adjusted) survival difference between carriers and non-carriers was statistically significant only among women who did not receive adjuvant chemotherapy, indicating that the disparity in survival might be eliminated through the use of chemotherapy. A similar result was reported by Goodwin et al, 2012 in a much smaller data set (72 BRCA2 carriers). Furthermore, in our study, the $\mathrm{HR}$ for $B R C A 2$ carriers who received chemotherapy (compared with no use) was 0.35 (95\% CI $=0.16-$ $0.80 ; P=0.01$ ) after adjustment for prognostic factors and other treatments, whereas this effect was not found for non-carriers. These observations and those of Goodwin et al suggest that chemotherapy should not be withheld from women with a BRCA2 mutation on the basis of ER status, but further studies are needed to support this clinical recommendation.

In 2013, we first proposed that carriers of the BRCA2 mutation 999del5 in Iceland have a poor prognosis if their tumours are ER-positive (Tryggvadottir et al, 2013) and this observation is confirmed in the current, much larger study. Contrary to expectation, in BRCA2 mutation carriers, positive ER status was positively correlated with positive lymph node status and with large tumour size, and tumour grade did not correlate with outcome. Among non-carriers the expected associates were observed. After adjusting for tumour size and lymph node status, the increased risk associated with positive ER status in BRCA2 carriers was no longer statistically significant. The basis for the unexpected association between a positive ER status and poor prognosis in BRCA2 carriers is unclear but these findings suggest that oestrogen signalling pathways might differ in cancers depending on the state of BRCA2. These data also suggest that luminal A characteristics based on IHC analyses may not be favourable in all women with breast cancer. Recent results from Iceland indicate an association between the loss of the intact BRCA2 allele and a positive ER status in mutation carriers (Stefansson et al, 2011). The BRCA2 protein is large and much remains to be understood about its functions and of the tissue-specific carcinogenic effects of BRCA2 mutations.

We found that among BRCA2 carriers with ER-positive breast cancer, mortality was not reduced with the use of hormonal therapy (tamoxifen) $(\mathrm{HR}=1.03 ; 95 \% \mathrm{CI}=0.41-2.60)$ but the confidence limits are wide. A similar result was reported by Goodwin et al, 2012. Further research is needed before tamoxifen should be discounted as adjuvant hormonal therapy for BRCA2 carriers.

We also saw a protective effect of mastectomy $v s$ lumpectomy in $B R C A 2$ carriers, albeit not statistically significant $(P=0.09)$. This is 
Table 4. Risk of breast cancer-specific death according to treatment among non-carriers and BRCA2 carriers (period of diagnosis 1980-2012), multivariate ${ }^{a}$

\begin{tabular}{|c|c|c|c|c|c|c|c|c|c|c|c|}
\hline & \multicolumn{5}{|c|}{ Non-carriers } & \multicolumn{5}{|c|}{ BRCA2 mutation } & \multirow[b]{2}{*}{$\begin{array}{c}P \text {-value } \\
\text { interaction }^{b}\end{array}$} \\
\hline & $\begin{array}{l}\text { Patients } \\
(n=369)\end{array}$ & $\begin{array}{l}\text { Deaths } \\
(n=71)\end{array}$ & HR & $95 \% \mathrm{Cl}$ & $P$-value & $\begin{array}{l}\text { Patients } \\
(n=187)\end{array}$ & $\begin{array}{l}\text { Deaths } \\
(n=71)\end{array}$ & HR & $95 \% \mathrm{Cl}$ & $P$-value & \\
\hline \multicolumn{11}{|l|}{ Surgery } & 0.007 \\
\hline $\begin{array}{l}\text { Lumpectomy } \\
\text { Mastectomy }\end{array}$ & $\begin{array}{l}153 \\
214\end{array}$ & $\begin{array}{l}26 \\
62\end{array}$ & $\begin{array}{c}1 \\
1.01\end{array}$ & $0.51-2.03$ & 0.97 & $\begin{array}{c}49 \\
138\end{array}$ & $\begin{array}{l}14 \\
57\end{array}$ & $\begin{array}{c}1 \\
0.49\end{array}$ & $0.21-1.11$ & 0.09 & \\
\hline \multicolumn{11}{|c|}{ Adjuvant chemotherapy } & 0.06 \\
\hline $\begin{array}{l}\text { None } \\
\text { Any } \\
\text { Anthracyclin } \\
\text { Nonanthracyclin }\end{array}$ & $\begin{array}{l}185 \\
175 \\
81 \\
94\end{array}$ & $\begin{array}{l}35 \\
50 \\
15 \\
35\end{array}$ & \begin{tabular}{c|}
1 \\
0.98 \\
1.41 \\
0.84
\end{tabular} & $\begin{array}{l}0.47-2.04 \\
0.54-3.69 \\
0.38-1.86\end{array}$ & $\begin{array}{l}0.96 \\
0.48 \\
0.67\end{array}$ & $\begin{array}{c}82 \\
101 \\
51 \\
49\end{array}$ & $\begin{array}{l}31 \\
40 \\
15 \\
24\end{array}$ & \begin{tabular}{c|}
1 \\
0.35 \\
0.36 \\
0.34
\end{tabular} & $\begin{array}{l}0.16-0.80 \\
0.13-0.98 \\
0.14-0.83\end{array}$ & $\begin{array}{l}0.01 \\
0.05 \\
0.02\end{array}$ & \\
\hline \multicolumn{11}{|l|}{ Radiation } & 0.13 \\
\hline $\begin{array}{l}\text { None } \\
\text { Any }\end{array}$ & $\begin{array}{l}167 \\
198\end{array}$ & $\begin{array}{l}41 \\
47\end{array}$ & \begin{tabular}{c|}
1 \\
0.87
\end{tabular} & $0.48-1.56$ & 0.64 & $\begin{array}{l}86 \\
98\end{array}$ & $\begin{array}{l}31 \\
40\end{array}$ & \begin{tabular}{c|}
1 \\
1.09 \\
\end{tabular} & $0.59-2.04$ & 0.78 & \\
\hline \multicolumn{11}{|c|}{ Adjuvant hormone therapy } & 0.16 \\
\hline $\begin{array}{l}\text { None } \\
\text { Any }\end{array}$ & $\begin{array}{l}206 \\
154 \\
\end{array}$ & $\begin{array}{l}64 \\
22 \\
\end{array}$ & \begin{tabular}{c|}
1 \\
0.65 \\
\end{tabular} & $0.32-1.33$ & 0.24 & $\begin{array}{l}94 \\
89 \\
\end{array}$ & $\begin{array}{l}36 \\
35 \\
\end{array}$ & \begin{tabular}{|c|}
1 \\
1.03 \\
\end{tabular} & $0.41-2.60$ & 0.95 & \\
\hline \multicolumn{12}{|c|}{$\begin{array}{l}\text { Abbreviations: } \mathrm{Cl}=\text { confidence interval; } \mathrm{HR}=\text { hazard ratio. } \\
\mathbf{a}_{\text {Model including year of birth, year of diagnosis, size, nodal status, grade, ER status and all other treatment categories. }} \\
\mathbf{b}_{\text {Interaction between } B R C A 2 \text { mutation status and the relevant variable. }}\end{array}$} \\
\hline
\end{tabular}

Table 5. Hazard ratios associated with a positive vs a negative BRCA2 mutation status, overall and according to ER status, and for women in different treatment categories (period of diagnosis 1980-2012)

\begin{tabular}{|c|c|c|c|}
\hline & HR & $95 \% \mathrm{Cl}$ & $P$-value \\
\hline BRCA2 & $1.85^{\mathrm{a}}$ & $1.35-2.52$ & $<0.001$ \\
\hline BRCA2 (multivariate) & $1.61^{\mathrm{b}}$ & $1.11-2.35$ & 0.01 \\
\hline $\begin{array}{l}\text { ER status } \\
\text { Positive } \\
\text { Negative }\end{array}$ & $\begin{array}{l}1.92^{\mathrm{b}} \\
1.12^{\mathrm{b}}\end{array}$ & $\begin{array}{l}1.20-3.05 \\
0.54-2.31\end{array}$ & $\begin{array}{l}0.006 \\
0.77\end{array}$ \\
\hline $\begin{array}{l}\text { Surgery } \\
\text { Lumpectomy } \\
\text { Mastectomy }\end{array}$ & $\begin{array}{l}4.16^{\mathrm{b}} \\
1.25^{\mathrm{b}}\end{array}$ & $\begin{array}{l}1.88-9.17 \\
0.82-1.93\end{array}$ & $\begin{array}{c}<0.001 \\
0.3\end{array}$ \\
\hline $\begin{array}{l}\text { Adjuvant chemotherapy } \\
\text { None } \\
\text { Any } \\
\text { Anthracycline } \\
\text { Non-anthracycline }\end{array}$ & $\begin{array}{l}2.38^{\mathrm{b}} \\
1.21^{\mathrm{b}} \\
1.31^{\mathrm{b}} \\
1.19^{\mathrm{b}}\end{array}$ & $\begin{array}{l}1.31-4.34 \\
0.74-2.00 \\
0.58-2.95 \\
0.61-2.27\end{array}$ & $\begin{array}{l}0.005 \\
0.45 \\
0.52 \\
0.62\end{array}$ \\
\hline $\begin{array}{l}\text { Radiation } \\
\text { None } \\
\text { Any }\end{array}$ & $\begin{array}{l}1.18^{b} \\
2.07^{b}\end{array}$ & $\begin{array}{l}0.68-2.06 \\
1.23-3.50\end{array}$ & $\begin{array}{c}0.55 \\
0.006\end{array}$ \\
\hline $\begin{array}{l}\text { Adjuvant hormone } \\
\text { therapy } \\
\text { None } \\
\text { Any }\end{array}$ & $\begin{array}{l}1.37^{b} \\
3.13^{b}\end{array}$ & $\begin{array}{l}0.85-2.21 \\
1.53-6.41\end{array}$ & $\begin{array}{c}0.2 \\
0.002\end{array}$ \\
\hline \multicolumn{4}{|c|}{$\begin{array}{l}\text { Abbreviations: } E R=\text { oestrogen receptor; } \mathrm{HR}=\text { hazard ratio. } \\
{ }^{\mathbf{a}} \text { Adjusted for year of birth and year of diagnosis. } \\
{ }^{\mathbf{b}} \text { Adjusted for year of birth, year of diagnosis, size, nodal status, grade, ER status and al } \\
\text { other treatment categories. }\end{array}$} \\
\hline
\end{tabular}

in keeping with the result of Metcalfe et al, 2014 in BRCA1 and $B R C A 2$ carriers and is likely the consequence of preventing new primary ipsilateral cancers. We were not able to compare the survival of women with unilateral $v s$ bilateral mastectomy in this study. Only four carriers were aware of their genetic status at the time of diagnosis and therefore bilateral mastectomies were not offered. Nevertheless, given the result presented here regarding unilateral mastectomy, coupled with the results of Metcalfe et al,
2014 and of Heemskerk-Gerritsen et al, 2015 is it rational to offer the option of bilateral mastectomy to women with breast cancer and a BRCA2 mutation. In non-carriers, the outcomes of patients treated with mastectomy and breast-conserving surgery were similar, in keeping with the results of key randomised controls trials (Fisher et al, 2002).

The study has several strengths, including a large number of patients, a long period of follow-up and access to pathology samples from 1935 onwards. Our study had a mean follow-up time of 13.6 years. An 80-year period of case ascertainment witnessed the introduction of chemotherapy and other current treatments. Both carriers and non-carriers were derived from the same database of breast cancer patients, the majority of patients were unselected with regards to family history and the majority of mutation carriers with breast cancer in the country were included. Genetic counselling for cancer was first established in Iceland in 2006 (Stefansdottir et al, 2013) and only four mutation carriers in the present study had knowledge of their carrier status at the time of diagnosis. Treatment was decided without respect to mutation status and therefore, prophylactic oophorectomies or mastectomies are not likely to have influenced the results.

There are several limitations as well. There is a potential concern for using archival tumour material for the IHC staining for ER status; however, the proportion of ER-positive tumours was similar in the first period (1935-1954) (67\%) as in 1955-2012 $(72 \%)$. This is a historical cohort study and treatments were not assigned at random, therefore the results concerning treatment need to be interpreted with caution. Furthermore, treatments have evolved since the first patients in this study were treated for their cancer. To minimise the potential impact of the changes in diagnostic methods and treatment during an 80-year period of study, we restricted the analyses of treatment effects to patients diagnosed from 1980 to 2012. Few women were treated with bilateral mastectomy and this could not be evaluated. HER-2 status was not assessed in this study. However, BRCA2 mutation carriers have a low prevalence of HER-2 amplifications (Honrado et al, 2005) and HER-2 status is not a likely confounder of the association reported here between a positive ER status and poor survival. This is the largest and most comprehensive study of the 
clinical course of breast cancer in BRCA2 carriers but is limited to 285 patients, all of whom had the same BRCA2 mutation (999del5). It is not clear to what extent our findings are generalisable to patients with other BRCA2 mutations.

In conclusion, we observed an adverse outcome associated with a positive ER status among women with breast cancer who carry a $B R C A 2$ mutation. We found a long-term survival disadvantage of mutation carriers, which might be mitigated by the use of adjuvant chemotherapy. The results suggest that neither a positive ER status nor low tumour grade should be used to withhold treatment from women with a BRCA2 mutation, but they require confirmation in other populations. The data presented here support the principle that precision medicine has the potential to sub-classify patients by host factors in order to provide appropriate treatment.

\section{ACKNOWLEDGEMENTS}

This work was supported by the Icelandic Cancer Society, the Icelandic Centre for Research (grant ID \#14193-051) and the Icelandic breast cancer research support group Göngum saman.

\section{CONFLICT OF INTEREST}

The authors declare no conflict of interest.

\section{REFERENCES}

Arason A, Gunnarsson H, Johannesdottir G, Jonasson K, Bendahl PO, Gillanders EM, Agnarsson BA, Jönsson G, Pylkäs K, Mustonen A, Heikkinen T, Aittomäki K, Blomqvist C, Melin B, Johannsson OT, Møller P, Winqvist R, Nevanlinna H, Borg A, Barkardottir RB (2010) Genome-wide search for breast cancer linkage in large Icelandic non-BRCA1/2 families. Breast Cancer Res 12(4): R50.

Byrski T, Gronwald J, Huzarski T, Grzybowska E, Budryk M, Stawicka M, Mierzwa T, Szwiec M, Wisniowski R, Siolek M, Dent R, Lubinski J, Narod S (2010) Pathologic complete response rates in young women with BRCA1-positive breast cancers after neoadjuvant chemotherapy. J Clin Oncol 28(3): 375-379.

Collins FS, Varmus H (2015) A new initiative on precision medicine. N Engl J Med 372(9): 793-795.

Fisher B, Anderson S, Bryant J, Margolese RG, Deutsch M, Fisher ER, Jeong JH, Wolmark N (2002) Twenty-year follow-up of a randomized trial comparing total mastectomy, lumpectomy, and lumpectomy plus irradiation for the treatment of invasive breast cancer. $N$ Engl J Med 347(16): 1233-1241.

Goodwin PJ, Phillips KA, West DW, Ennis M, Hopper JL, John EM, O’Malley FP, Milne RL, Andrulis IL, Friedlander ML, Southey MC, Apicella C, Giles GG, Longacre TA (2012) Breast cancer prognosis in BRCA1 and BRCA2 mutation carriers: an International Prospective Breast Cancer Family Registry population-based cohort study. J Clin Oncol 30(1): 19-26.

Gudbjartsson DF, Helgason H, Gudjonsson SA, Zink F, Oddson A, Gylfason A, Besenbacher S, Magnusson G, Halldorsson BV, Hjartarson E, Sigurdsson GT, Stacey SN, Frigge ML, Holm H, Saemundsdottir J, Helgadottir HT, Johannsdottir H, Sigfusson G, Thorgeirsson G, Sverrisson JT, Gretarsdottir S, Walters GB, Rafnar T, Thjodleifsson B, Bjornsson ES, Olafsson S, Thorarinsdottir H, Steingrimsdottir T, Gudmundsdottir TS, Theodors A, Jonasson JG, Sigurdsson A, Bjornsdottir G, Jonsson JJ, Thorarensen O, Ludvigsson P, Gudbjartsson H, Eyjolfsson GI, Sigurdardottir O, Olafsson I, Arnar DO, Magnusson OT, Kong A, Masson G, Thorsteinsdottir U, Helgason A, Sulem P, Stefansson K (2015) Large-scale whole-genome sequencing of the Icelandic population. Nat Genet 47(5): 435-444.

Heemskerk-Gerritsen BA, Rookus MA, Aalfs CM, Ausems MG, Collée JM, Jansen L, Kets CM, Keymeulen KB, Koppert LB, Meijers-Heijboer HE, Mooij TM, Tollenaar RA, Vasen HF, HEBON, Hooning MJ, Seynaeve C (2015) Improved overall survival after contralateral risk-reducing mastectomy in BRCA1/2 mutation carriers with a history of unilateral breast cancer: a prospective analysis. Int J Cancer 136(3): 668-677.

Honrado E, Benítez J, Palacios J (2005) The molecular pathology of hereditary breast cancer: genetic testing and therapeutic implications. Mod Pathol 18(10): 1305-1320.

Huzarski T, Byrski T, Gronwald J, Górski B, Domagala P, Cybulski C, Oszurek O, Szwiec M, Gugala K, Stawicka M, Morawiec Z, Mierzwa T, Janiszewska H, Kilar E, Marczyk E, Kozak-Klonowska B, Siolek M, Surdyka D, Wisniowski R, Posmyk M, Sun P, Lubinski J, Narod SA (2013) Ten-year survival in patients with BRCA1-negative and BRCA1-positive breast cancer. J Clin Oncol 31(26): 3191-3196.

Johannesdottir G, Gudmundsson J, Bergthorsson JT, Arason A, Agnarsson BA, Eiriksdottir G, Johannsson OT, Borg A, Ingvarsson S, Easton DF, Egilsson V, Barkardottir RB (1996) High prevalence of the 999del5 mutation in Icelandic breast and ovarian cancer patients. Cancer Res 56(16): 3663-3665.

Lee JM, Ledermann JA, Kohn EC (2014) PARP Inhibitors for BRCA1/2 mutation-associated and BRCA-like malignancies. Ann Oncol 25(1): $32-40$.

Metcalfe K, Gershman S, Ghadirian P, Lynch HT, Snyder C, Tung N, Kim-Sing C, Eisen A, Foulkes WD, Rosen B, Sun P, Narod SA (2014) Contralateral mastectomy and survival after breast cancer in carriers of BRCA1 and BRCA2 mutations: retrospective analysis. BMJ 348: g226.

Metcalfe K, Lynch HT, Foulkes WD, Tung N, Kim-Sing C, Olopade OI, Eisen A, Rosen B, Snyder C, Gershman S, Sun P, Narod SA (2015) Effect of oophorectomy on survival after breast cancer in BRCA1 and BRCA2 mutation carriers. JAMA Oncol 1(3): 306-313.

Rennert G, Bisland-Naggan S, Barnett-Griness O, Bar-Joseph N, Zhang S, Rennert HS, Narod SA (2007) Clinical outcomes of breast cancer in carriers of BRCA1 and BRCA2 mutations. N Engl J Med 357(2): 115-123.

Robson ME, Chappuis PO, Satagopan J, Wong N, Boyd J, Goffin JR, Hudis C, Roberge D, Norton L, Bégin LR, Offit K, Foulkes WD (2004) A combined analysis of outcome following breast cancer: differences in survival based on BRCA1/BRCA2 mutation status and administration of adjuvant treatment. Breast Cancer Res 6(1): R8-R17.

Sigurdardottir LG, Jonasson JG, Stefansdottir S, Jonsdottir A, Olafsdottir GH, Olafsdottir EJ, Tryggvadottir L (2012) Data quality at the Icelandic Cancer Registry: comparability, validity, timeliness and completeness. Acta Oncol 51(7): 880-889.

Sjölander A, Greenland S (2013) Ignoring the matching variables in cohort studies-when is it valid and why? Stat Med 32(27): 4696-4708.

Snaedal G (1965) Cancer of the Breast. A clinical study of treated and untreated patients in Iceland 1911-1955. Acta Chirurgica Scandinavica 90(Suppl 338): $1+$.

Stefansdottir V, Arngrimsson R, Jonsson JJ (2013) Iceland-genetic counseling services. J Genet Couns 22(6): 907-910.

Stefansson OA, Jonasson JG, Olafsdottir K, Bjarnason H, Th Johannsson O, Bodvarsdottir SK, Valgeirsdottir S, Eyfjord JE (2011) Genomic and phenotypic analysis of BRCA2 mutated breast cancers reveals cooccurring changes linked to progression. Breast Cancer Res 13(5): R95.

Thorlacius S, Olafsdottir G, Tryggvadottir L, Neuhausen S, Jonasson JG, Tavtigian SV, Tulinius H, Ogmundsdottir HM, Eyfjörd JE (1996) A single BRCA2 mutation in male and female breast cancer families from Iceland with varied cancer phenotypes. Nat Genet 13(1): 117-119.

Thorlacius S, Sigurdsson S, Bjarnadottir H, Olafsdottir G, Jonasson JG, Tryggvadottir L, Tulinius H, Eyfjörd JE (1997) Study of a single BRCA2 mutation with high carrier frequency in a small population. Am J Hum Genet 60(5): 1079-1084.

Tilanus-Linthorst MM, Bartels KC, Alves C, Bakri B, Crepin E, van den Ouweland A, Klijn JG, Meijers-Heijboer H, Brekelmans CT (2006) Selection bias influences reported contralateral breast cancer incidence and survival in high risk non-BRCA1/2 patients. Breast Cancer Res Treat 95(2): 117-123.

Tryggvadottir L, Olafsdottir EJ, Gudlaugsdottir S, Thorlacius S, Jonasson JG, Tulinius H, Eyfjord JE (2003) BRCA2 mutation carriers, reproductive factors and breast cancer risk. Breast Cancer Res 5(5): R121-R128.

Tryggvadottir L, Olafsdottir EJ, Olafsdottir GH, Sigurdsson H, Johannsson OT, Bjorgvinsson E, Alexiusdottir K, Stefansson OA, Agnarsson BA, Narod SA, Eyfjord JE, Jonasson JG (2013) Tumour diploidy and survival in breast cancer patients with BRCA2 mutations. Breast Cancer Res Treat 140(2): $375-384$ 
Tulinius H, Olafsdottir GH, Sigvaldason H, Arason A, Barkardottir RB, Egilsson V, Ogmundsdottir HM, Tryggvadottir L, Gudlaugsdottir S, Eyfjord JE (2002) The effect of a single BRCA2 mutation on cancer in Iceland. J Med Genet 39(7): 457-462.
This work is published under the standard license to publish agreement. After 12 months the work will become freely available and the license terms will switch to a Creative Commons AttributionNonCommercial-Share Alike 4.0 Unported License.

Supplementary Information accompanies this paper on British Journal of Cancer website (http://www.nature.com/bjc) 